ppi $201502 Z U 4645$

Esta publicación científica en formato digital es continuidad de la revista impresa ISSN-Versión Impresa 0798-1406 / ISSN-Versión on line 2542-3185Depósito legal pp $197402 Z$ U34

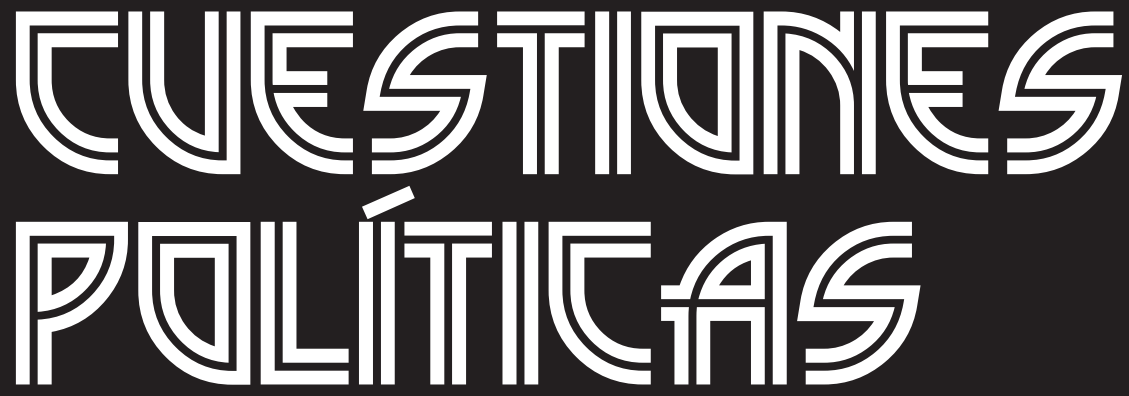

Instituto de Estudios Políticos y Derecho Público "Dr. Humberto J. La Roche" de la Facultad de Ciencias Jurídicas y Políticas de la Universidad del Zulia Maracaibo, Venezuela
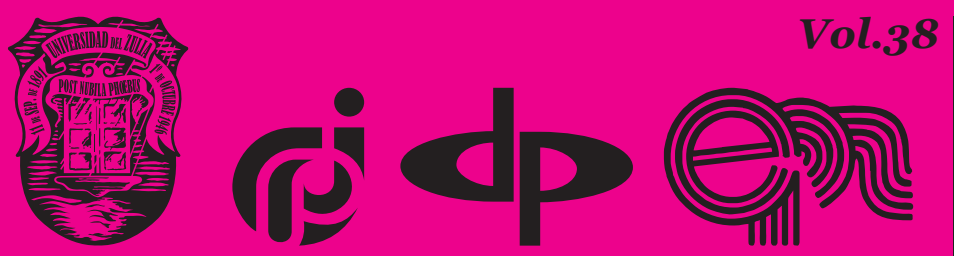

$N^{\circ}$ Especial 1era Parte 2020 


\title{
Organizational and pedagogical conditions for the determination of gifted children and support policies for effective management in an educational institution
}

\author{
DOI: https://doi.org/10.46398/cuestpol.38e.12
}

\author{
Mihail V. Kozhevnikov * \\ Irina $V$. Lapchinskaia ** \\ Natalia Y. Korneeva \\ Petr Yu. Romanov **** \\ Natalia $V$. Uvarina $* * * * *$
}

\section{Abstract}

The article describes the organizational and pedagogical conditions for the determination and support of the effective management of gifted children in an educational institution based on personality-oriented educational technologies. The authors pay special attention to determining the research predisposition in the learning process (cognition), which can be considered as the most important form of manifestation of the research position of a gifted child. This position is most clearly expressed in problem situations, suspenseful and unusual situations. The approach to teaching gifted children is not based on the reproductive activity of a student in the assimilation of knowledge, skills, but on a creative search that leads to the development of individual intellectual and creative potential. In the main conclusions, the authors of the article point out the important role of the development of the educational environment, which includes three components: spatialsubject, social and technological. The educational environment must consider the age, gender, national characteristics, level of intellectual and mental development of a student's personality, all of which demands the implementation of a set of public policies in the education sector.

Keywords: definition of educational policies; personality-oriented

\footnotetext{
* South Ural State Humanitarian Pedagogical University, 69, Lenin Avenue, Chelyabinsk, Russian Federation. ORCID ID: https://orcid.org/oooo-0002-1147-6720.Email: info@ores.su

** South Ural State Humanitarian Pedagogical University, 69, Lenin Avenue, Chelyabinsk, Russian Federation. ORCID ID: https://orcid.org/oooo-0003-1386-9592. Email: russia@prescopus.com

*** South Ural State Humanitarian Pedagogical University, 69, Lenin Avenue, Chelyabinsk, Russian Federation. ORCID ID: https://orcid.org/oooo-0002-2261-4682. Email: editor@ores.su

****Nosov Magnitogorsk State Technical University, 38, Lenin Avenue, 45500o, Chelyabinsk Region, Magnitogorsk, Russia. ORCID ID: https://orcid.org/oooo-0002-5579-0172. E-mail: info@ores.su

*****South Ural State Humanitarian Pedagogical University, 69, Lenin Avenue, Chelyabinsk, Russian Federation. ORCID ID: https://orcid.org/oooo-0002-1118-8294. Email: global@ores.su
} 
Mihail V. Kozhevnikov, Irina V. Lapchinskaia, Natalia Y. Korneeva, Petr Yu. Romanov y Natalia $V$. Uvarina

technologies; pedagogical support of gifted children; organizational and pedagogical conditions; development environment.

\section{Condiciones organizativas y pedagógicas para la determinación de los niños superdotados y políticas de apoyo para la gestión eficaz en una institución educativa}

\section{Resumen}

El artículo describe las condiciones organizativas y pedagógicas para la determinación y el apoyo de la gestión eficaz de los niños superdotados en una institución educativa basada en tecnologías educativas orientadas a la personalidad. Los autores prestan especial atención a la determinación de la predisposición a la investigación en el proceso de aprendizaje (cognición), que puede considerarse como la forma más importante de manifestación de la posición de investigación de un niño superdotado. Esta posición se expresa con mayor claridad en situaciones problemáticas, situaciones de suspenso e inusuales. El enfoque de la enseñanza de los niños superdotados no se basa en la actividad reproductiva de un alumno en la asimilación de conocimientos, habilidades, sino en una búsqueda, creativa, que conduce al desarrollo de un potencial intelectual y creativo individual. En las principales conclusiones, los autores del artículo señalan el importante papel del desarrollo del entorno educativo, que incluye tres componentes: espacial-sujeto, social y tecnológico. El entorno educativo debe tener en cuenta la edad, el género, las características nacionales, el nivel de desarrollo intelectual y mental de la personalidad de un estudiante, todo lo cual demanda de la implementación de un conjunto de políticas públicas en el sector educación.

Palabras clave: definición de políticas educativas; tecnologías orientadas a la personalidad; apoyo pedagógico de niños superdotados; condiciones organizativas y pedagógicas; entorno de desarrollo.

\section{Introduction}

Modern management of the education system is based on international quality standards that consider activity as a process. The pedagogical conditions created by us should provide a high-quality organization for gifted child determination and support in an educational organization. 
The basis of the search for a different, not traditional model of gifted child teaching, which will not be based on the student's reproductive activity in the assimilation of knowledge, skills, but on search, and creativity, is the special creative potential that a gifted child has, as well as recognition the development of a creative personality as one of the priority goals of training. The most suitable strategic trend for a gifted child teaching is creative learning, i.e. the learning focused on child's creative potential maintaining and development and assuming the child's personal activity in the process of generating and posing the problem, searching for and implementing its solution. This became the reason for consideration of practice-widebased models of creative learning that were widespread abroad and their possibilities and application boundary discussion.

The implementation of a child's research activity has an impact on his research position development, which is most clearly expressed in problem situations, the situations of suspense, unusualness, and development in the broad sense of the word. During the school years, the identification of a research predisposition in the process of learning (cognition), which can be considered as the most important form of a person's research position manifestation, is of the greatest importance.

In addition to the "internal" factors that ensure the development of general giftedness during the school period, N.B. Shumakova also identifies "external" conditions that contribute to the development of research activity. To such conditions, she includes the content of training and teaching methods, which should fully take into account the special cognitive needs and capabilities of gifted children, especially their personality. Also, the social approval of a child's creativity is one of important conditions, and a high assessment of his research activity, which is mainly carried out by recognition from a teacher(s) and close relatives during school years (Shumakova, 2017).

It is useful for us to consider the activities of an educational organization in accordance with GOST R ISO 9000:2001 standards as a targeted set of interrelated activities of an educational organization aimed at creation the quality of graduate's personality readiness (at the exit) for activities which are of value to its internal and external consumers. The external consumers of an educational institution are the state and society, while the internal consumers are parents, students, and teachers.

We believe that personality-oriented educational technologies are becoming an effective means to manage the process of gifted child determination and support in an educational organization when they implement a set of organizational and pedagogical conditions, which we presented in the table. 
Mihail V. Kozhevnikov, Irina V. Lapchinskaia, Natalia Y. Korneeva, Petr Yu. Romanov y Natalia $V$. Uvarina

\section{Problem Relevance}

The problem of intellectual and creative potential determination and support among the young generation is associated with human resource quality improvement not only in Kazakhstan, and Russia, but throughout the world. Pedagogical support is understood as a specially organized process of creative and intellectual potential disclosure promotion among talented and gifted children. Thus, the support of talented and gifted children requires the organization of conditions for their development in an educational institution.

Gifted children need a rich developmental environment in which their social activity, initiative, independence, and freedom of creative expression can be supported and realized through purposefully various means.

As practice shows, a modern school, as a rule, has a plan for working with gifted students, and some schools have developed their own concepts for gifted child development. However, the level of such plan implementation does not fully correspond to the stated learning outcomes. The organization of pedagogical support for gifted children is declared, but, as practice shows, work with gifted children in a common school is often represented by separate events, according to external programs, promotions and projects offered from above. At the same time, there is a tendency of insufficient attention to this problem on the part of teachers.

The analysis of the program content shows the lack of a holistic view on the issues of gifted child determination and support in an educational institution; the managerial aspects of the giftedness problem are not well developed. Teachers do not fully master the methodology for talented child and hidden and potential giftedness determination, therefore they do not take into account the psychoemotional, cognitive, behavioral characteristics of gifted children. This allows us to consider the topic of our study as an urgent problem (Dolgova et al., 2019).

\section{Problem Study}

The problem of giftedness was solved by pedagogy, psychology, and philosophy in theory and practice and at different stages. Researchers addressed the following issues:

- the identification and development of giftedness and creativity (a fundamental justification is given in the works by L.S. Vygotsky, S.L. Rubinshtein, B.M. Teplov, V.N. Myasishchev, J. Renzulli, O.K. 
Tikhomirova, A.V. Brushlinsky, L.A. Wenger, Ya.A. Ponomarev, D.B. Bogoyavlenskaya and others);

- the works by N.S. Leites, B.M. Teplova et al. are devoted to gifted child general and special ability support and development.

The works of psychologists, methodologists and practicing educators develop a system of didactic principles, curricula, and electives to solve the problem of gifted child determination and support. So, the study of the Russian scholar N.S. Leites, who studied the individual typological and age-related characteristics of intellectually gifted children, is considered as the most complete and deep (Leites, 2008). The work of Kazakhstani researchers also found the solution to the urgent problem of gifted child determination and support. The works by T.I. Smagliy, R.R. Bikbulatov revealed the psychological characteristics of intellectually gifted students (Smagliy and Bikbulatov, 2017).

The study by W.B. Zheksenbaeva examined the issues of theory and practice of working with gifted children in the conditions of the Republic of Kazakhstan, studied the aspects of giftedness diagnosis (Zheksenbaeva, 2004). The possibilities of differentiating educational preparation in the development of gifted children are studied in the works by M.Zh. Zhadrina (Zhadrina, 2000). They defended the candidate dissertations defining the conditions for the development of giftedness among schoolchildren (I.A. Bevz, E.O. Omar, E.E. Tleulova and others).

The abovementioned works develop the system of didactic principles, curricula, and electives to solve the problem of gifted child determination and support. The works emphasized the importance and necessity of a special educational environment creation for the development of gifted student intellectual potential.

\section{Study Hypothesis}

As the hypothesis of the study, we put forward the following assumption: the development process of talented and gifted student management in an educational organization will be more effective if the following organizational and pedagogical conditions are implemented in the management process:

- managing a system identifying and supporting talented and gifted students on the basis of a reliable measurement of activity.

- organization of a developing educational environment based on personality-oriented educational technologies.

- inclusion of all subjects of education in project activities based on personality-oriented educational technologies. 
Mihail V. Kozhevnikov, Irina V. Lapchinskaia, Natalia Y. Korneeva, Petr Yu. Romanov y Natalia $V$. Uvarina

\section{Research Methods}

The methodology for a comprehensive assessment of the process identifying and supporting giftedness involves the participation of an administrator, a psychologist, class teachers, teachers, parents, as well as self-esteem of students.

The main monitoring method is a questionnaire, but in addition to this, testing is also used, certain conversations and observations are carried out, processing algorithms and interpretation of the research results are performed.

The most high-quality and effective implementation of diagnosing the giftedness of schoolchildren by teachers, requires specially developed techniques. Performance indicators for managing the process of giftedness determination and support are developed in the works of experts.

In our opinion, such techniques, first, should be aimed at identifying the levels of a child cognitive and personal sphere development. At the same time, they must be based on the principle of minimum sufficiency.

Unfortunately, in educational practice, the study of giftedness it is often limited to intelligence coefficient (IQ) evaluation, which is determined using psychometric intelligence tests. At the same time, the fact that the use of these tests has a number of limitations is ignored: most of them were created not to determine intellectual or creative giftedness, but for other purposes (mental retardation, academic performance prediction, career guidance, professional selection, etc.); many tests measure a specific intellectual ability (the development of specific mental operations); psychometric tests poorly predict the level of gifted child achievement. Two conclusions follow from this:

1) psychometric tests must be applied after the procedure of a child determination as gifted (not for and not until a decision is made) in order to organize the psychological and pedagogical assistance he needs.

2) psychometric tests are useful for tracking the dynamics of specific child giftedness manifestations.

Thus, psychometric tests are just one of many other information sources in the process of a gifted child determination.

As was already noted, domestic scholars recognize an integrated approach to gifted child determination, the essence of which is the use of various methods: 
- child monitoring methods.

- special psychodiagnostic trainings.

- expert assessment of children's behavior.

- conduct of "trial" classes according to special programs.

- evaluation of creative activity products.

- organization of intellectual events (subject Olympiads, conferences, competitions, contests, shows, festivals, etc.).

- conduct of psychodiagnostic research using variable methods, etc.

However, researchers warn that a comprehensive approach to child giftedness determination does not completely eliminate mistakes. Pedagogical technologies that meet the requirements of interaction, activation, a personality-oriented and activity-oriented approach implementation are the following ones:

- Organization of student research activities (RA).

- "brainstorming", drawing up intelligent map diagrams and other methods of divergent thinking development.

- the development of critical thinking.

- development of reflection.

- problematic methods.

- dialogue methods, etc.

We use all the methods listed above. The feature of the dialogue method is the material presentation organization in the form of questions and answers. We use different types of dialogue in the organization of training, in each part of the lesson:

- Socratic dialogue - questions without a ready answer - contribute to the activation of student's thinking.

- level dialogue - organization of dialogs of various levels: teacherstudent, student-student, teacher-group of students - helps to change roles, change activities, maintains interest in a lesson.

Such lessons are always distinguished by the activation of mental activity, which is also noted by the students themselves.

Dialogue interaction implies the equality of positions in communication. It is an excellent method to implement a personality-oriented organization of the educational process. 
Mihail V. Kozhevnikov, Irina V. Lapchinskaia, Natalia Y. Korneeva, Petr Yu. Romanov y Natalia $V$. Uvarina

\section{Main Part}

The experimental work was carried out during the academic years 2017-2019 based on the State School No. 6 in Lisakovsk, the Republic of Kazakhstan.

The pilot work was attended by 770 students and 60 teachers.

The purpose of the experimental work was to evaluate the effectiveness of organizational and pedagogical conditions in practice for an effective management of gifted student determination and support system based on personality-oriented technologies.

The objectives of the experimental study were the following ones:

1. Determination of the initial level of school activity.

2. Testing a certain set of organizational and pedagogical conditions for an effective management of gifted student determination and support system based on personality-oriented technologies.

3. The study of management effectiveness dynamics concerning gifted student determination and support system based on personalityoriented technologies.

The basis for the work carried out effectiveness determination is to increase the level of students' creative activity development as the result of created organizational and pedagogical conditions in the educational space of school.

We have identified the following indicators the educational environment development:

- the level of teacher innovative activity.

- the level of educational program innovative component.

- the degree of innovative forms and method implementation in team activities.

- the level of pupil innovation mastery, etc.

The study had been conducted since September 2, 2017 till October 27, 2019. It was attended by 280 children of secondary and senior school (7-11 grades) of the State Institution "Secondary School No. 6", 110 boys and 170 girls.

Anticipating the study to assess the existing level of giftedness development among students during the experimental work, we conducted a survey among schoolteachers in order to identify the most important methods, forms and means of work organization with gifted children. 
The teachers revealed the following main signs of giftedness:

- an integrative feature of giftedness concept, including the intellectual, creative, and communicative components (50\%).

- giftedness as the psyche trait (30\%).

- the ability of an individual to implement in the creative, educational field (10\%).

Teachers named the most important methods of work with gifted and talented children:

- search, design, research methods (60\%).

- active teaching methods (game, training, ICT use, etc.) (30\%).

The most effective forms of educational process organization for gifted children:

- design and research activities (60\%),

- gaming, training (30\%),

- paired, group (10\%).

Teachers named the effective means of working with gifted children:

- research activities (50\%).

- dialogue activity (40\%).

- ICT use (20\%).

In the questionnaire, we proposed several possible reasons for the lack of teacher willingness to work with gifted children. Interviewees had the opportunity to select several of them. The results showed that the following three were the most relevant (33.8\% of respondents chose them):

- there is no necessary knowledge, skills and abilities - they were not obtained at the pedagogical educational institution.

- no time for self-education.

- lack of necessary information.

But nevertheless, despite the existence of barriers of an objective and subjective nature, teachers consider it is possible to improve in this area. To do this, they use various sources of information, the most accessible and popular among them are the following ones:

- Internet resources (70.2\% of respondents).

- continuing education courses (48.1\%). 
Mihail V. Kozhevnikov, Irina V. Lapchinskaia, Natalia Y. Korneeva, Petr Yu. Romanov y Natalia $V$. Uvarina

190

Organizational and pedagogical conditions for the determination of gifted children and support policies for effective management in an educational institution.

- methodical journals in the subject (42.9\%).

- psychological and pedagogical literature on the problem (37.7\%).

- attendance and discussion of open lessons, as a live exchange of experience with colleagues (28.6\%).

Based on the analysis of the teacher survey who had the experience of working with gifted children, we found that the following criteria for giftedness are recognized as the most effective in teaching practice:

- the level of knowledge, claims, motivation, cognitive activity (70\% of teachers).

- the results of gifted child practical activities (25\% of teachers).

- outstanding cognitive data, creativity (10\% of teachers).

Among diagnostic methods, 30\% of teachers noted the methodology by J. Renzulli; 20\% - IQ test; the KOS technique (Sinyavsky and Fedorishin) and the D.I. Bogoyavlensky methods - 5\%.

We made the following conclusion: the modern school is still sensitive only to children with obvious giftedness. This often leads to the fact that their abilities are exploited with the expectation of quick results in work, without any prospect for the targeted development of students. Potentially gifted schoolchildren and the children with a disharmonious type of giftedness development are left without attention, and after all, when appropriate work is organized with them, they could show their bright and outstanding abilities.

It should be noted that in a common secondary school, it is the teacher who is tasked with gifted and talented child determination. And although we also use giftedness self-assessment questionnaires for students in our work, we believe that the selection process by a teacher is more reliable.

During the diagnostic stage, we used the method to monitor the behavior of schoolchildren. In the process of observation, the task was set to diagnose the frequency of gifted child characteristics manifestation identified by J. Renzulli. The author compiled the scales to characterize cognitive, motivational, creative, as well as leadership areas.

We also applied P. Torrens figure test to assess the development of students' creative giftedness.

The results of the study showed that modern schoolchildren do not have sufficient preparation for creative intellectual work. An average student has a rather low level of cognitive motivation, and the skills of strong-willed self-regulation are practically absent; he often seeks to find an easier way to achieve positive learning outcomes. 
All mentioned above is confirmed by a survey that we conducted on social networks. As the results show:

- less than $8.5 \%$ of adolescents enjoy the process of cognition,

- the need to perform independent creative tasks are experienced only by $2.1 \%$ of respondents,

- $8.4 \%$ of students want "teacher to explain more clearly,"

- $14.7 \%$ of adolescents want the school curriculum to be "easier".

Of all the schoolchildren participating in the survey, $29.4 \%$ wished to have a variety of studies so that "the lessons would be in the form of a discussion or games."

It seems possible to overcome this situation completely only if the teachers are motivated and prepared for the development of intellectual, creative, and personal potential of gifted students, and at the same time of the rest of the students.

Thus, in the course of our study, we identified not only positive features in the modern school activities, but also the necessary aspects to solve the problems of training, education and development among gifted students.

The following factors are considered as positive. The vast majority of our respondents understand the urgent need to organize special work for the development of gifted children at high school. Teachers know the basic characteristics of gifted child cognitive activity and behavior and are aware of their problem causes. Most of the respondents have already worked with gifted students. Teachers improve their knowledge in this direction, for which they use various sources of information (Kozhevnikov and Lapchinskaya, 2019).

Besides, it is also positive that almost half of the respondents take a wide range of measures aimed at student development. Teachers develop experience of research, cognitive activity and creative abilities among students.

Nevertheless, we ascertain the fact that two-thirds of the respondents feel insufficient willingness to interact with gifted children, and some teachers are not at all ready to develop interaction. One third of teachers do not have sufficient knowledge of the methods for diagnosing giftedness in children, research skills, and they do not have enough knowledge about the technologies for a gifted child intellectual, personal, and creative potential development. Most of the teachers justify their incompetence of working with gifted students by external circumstances. The problem of educating parents about the development of child giftedness has not been resolved. Material stimulation of teacher additional efforts and encouragement of their talented students is very low. 
Mihail V. Kozhevnikov, Irina V. Lapchinskaia, Natalia Y. Korneeva, Petr Yu. Romanov y Natalia $V$. Uvarina

The results of the ascertaining experiment served as the basis for the organization and implementation of organizational and pedagogical conditions aimed at effective management of the development process among gifted children in the educational space of the secondary school No. 6 (Lisakovsk).

We believe that personality-oriented educational technologies are becoming an effective means of managing the process of gifted child determination and support in an educational organization when they implement the set of organizational and pedagogical conditions that we presented in the table.

\section{TABLE1: Organizational and pedagogical conditions for educational organization management effectiveness based on personality-oriented educational technologies}

\begin{tabular}{|l|l|l|}
\hline \multicolumn{1}{|c|}{ Condition } & \multicolumn{1}{c|}{ Content } & \multicolumn{1}{c|}{ Result } \\
\hline $\begin{array}{l}\text { Educational institution } \\
\text { management based on } \\
\text { a reliable measurement } \\
\text { of activity }\end{array}$ & $\begin{array}{l}\text { Includes psychological } \\
\text { and pedagogical } \\
\text { monitoring of student } \\
\text { cognitive abilities }\end{array}$ & $\begin{array}{l}\text { Timely identification of } \\
\text { problems among gifted } \\
\text { children, the ability to } \\
\text { adjust the process of } \\
\text { giftedness support and } \\
\text { development timely }\end{array}$ \\
\hline $\begin{array}{l}\text { Organization of a } \\
\text { personality-oriented } \\
\text { developing educational } \\
\text { environment }\end{array}$ & $\begin{array}{l}\text { Includes the use of } \\
\text { student-centered } \\
\text { educational technology } \\
\text { and personal self- } \\
\text { development }\end{array}$ \\
\hline $\begin{array}{l}\text { Organization of } \\
\text { research activity }\end{array}$ & $\begin{array}{l}\text { Inclusion of all subjects } \\
\text { of education in project } \\
\text { activities }\end{array}$ & $\begin{array}{l}\text { Solves the problems of } \\
\text { value attitude development }\end{array}$ \\
\hline
\end{tabular}

Own elaboration based on the research objective.

The implementation of the first condition - the use of the system to monitor the quality of the educational process - made it possible to track the dynamics of schoolchild training in the group as a whole and for each student. To this end, we used tests and individual maps to analyze the status and dynamics of the development of a child's educational activity quality.

Based on the completed map, the methodology by J. Renzulli, and Torrens, as well as the observation for each student, monitoring was conducted, taking into account the comprehensive identification of giftedness, as well as the timely identification of psychological and pedagogical problems. A psychological and pedagogical conclusion was drawn up, a map of giftedness was drawn up, the possibility of introducing the construction of possible individual development paths was developed. 
During implementation of the second condition - the organization of a personality-oriented developing educational environment, - we proceeded from understanding it as such an educational environment, "which provides opportunities that allow all subjects of the educational process to self-develop." According to Yasvin, a set of these features includes:

- the opportunities that allow a subject to satisfy and develop his needs on the entire hierarchical ladder up to self-actualization.

- the opportunities, using which a person assimilates social values and organically transforms them into internal values. In combination, they make a developing psychological and pedagogical potential of the environment (Yasvin, 2007).

A developing educational environment is formed by three components: spatial-subject, social and technological. The spatial-subject component is represented by the architecture of a school building, the degree of openness and closure of structures of intra-school design, the size and spatial structure of the premises in a school building, the ease of their spatial change, the possibility and breadth of spatial movements of subjects, etc. This component characterizes not so much different spatial and subject "units": rooms, furniture, appliances, etc., but the ways of their functioning in a particular educational field.

The social component consists of the "human factor", the methods of interpersonal interaction of all subjects of the educational process, which require the adoption and assistance of each subject, regardless of his personal identity specifics, as well as of any person discrimination prevention by any criterion, etc.

The technological component consists of programs, technologies, forms, methods, learning styles, it conveys the essential connections of the spatialsubject and social components that provide developmental opportunities to each child.

An integrative criterion that determines the quality of a developing educational environment is the level of this environment ability to provide all subjects of the educational process with a set of opportunities that provides effective personal and professional self-development.

Children with a sufficiently high creative potential in such an environment can live in a state of creativity more often that integrates a child's cognitive, operational, emotional and personal spheres.

The third condition is the organization of research activities by inclusion of all subjects of education in project activities.

Work on educational activity conduct with intellectually gifted children was also built through the organization of project activities. The project 
Mihail V. Kozhevnikov, Irina V. Lapchinskaia, Natalia Y. Korneeva, Petr Yu. Romanov y Natalia $V$. Uvarina

method forms the basis of project training, the meaning of which is to create conditions for students to learn the educational material in the process of project implementation independently.

We developed and conducted individual classes of the group "Learning to create a project", which were conducted according to the plan once a week. 34 hours of classes were held in total. In the process of the group work, we used the research and design teaching method. The main characteristic of the research method is that it is the method of student attraction to independent and direct observations, on the basis of which they establish connections between objects and phenomena of reality, draw conclusions, and learn patterns. Its main components are the identification of problems, the development and formulation of hypotheses, observations, experiments, as well as the judgments and conclusions made on their basis.

The project method of training is a certain way of organized search, research activities of students, individual or group, which provides not only the achievement of a particular result, designed as a specific practical output, but the organization of this result achievement process with the obligatory presentation of these results

The task of a modern teacher is to give the traditional tasks a research or design form.

Students use the "My Achievements" card as a self-assessment of their activities. We also used a rating system to evaluate the performance of a gifted student, describing the amount of participation in Olympiads and competitions.

To determine the effectiveness of organizational and pedagogical condition implementation after a formative impact conduct, we performed testing using the same methods. The change of gifted child number was the sign of the performed work effectiveness.

The results of the control experiment showed that the level of development of students' giftedness increased as compared with the ascertaining stage. The amount of students with the creative talent level of above the age norm increased by $4 \%$, which amounted to $30 \%$ of the number of subjects.

The development of a creative environment is evidenced by group collectivist perception level increase. During the control stage of our study, they revealed the following:

- individualistic perception of the group decreased by $16.6 \%$ and amounted to $50 \%$;

- pragmatic perception of the group remained at the same level;

- collectivist perception was revealed among 7 teenagers, which amounted to $25 \%$ of the total number of students in the class. 
As observation shows, student became more united. This outcome is the result of work in the whole group on the creation of a creative learning environment, through psychological training aimed at communication improvement in the group. A larger number of children regard the group as a value, which is manifested by the desire to put the solution to the group problems in one of the most significant places. The guys began to show more interest both in the goal achievement by each member of the group, and in the achievement of goals by the group in general. Students with a collectivist type of perception of a group are ready to contribute to group activity, they show a need for collective forms of work.

\section{Conclusions}

The objectives of our experimental study were the following ones:

1. Determination of school activity initial level.

2. Testing a specific set of organizational and pedagogical conditions for the management effectiveness concerning the system for talented and gifted student determination and support based on personalityoriented technologies.

3. Studying the effectiveness dynamics concerning the system for talented and gifted student determination and support based on personality-oriented technologies.

The basis for the work carried out work effectiveness determination is to increase the level of students' creative activity development as the result of created organizational and pedagogical conditions in the educational space of the school. The criterion for the development of the educational environment, based on the determination of quantitative indicators is the number of children participating in contests, competitions and research events engaged in creative associations of an educational institution; statistics on the organization of a system for gifted child support at school, the needs of children and parents.

The implementation of the conditions is aimed at creation of a system to manage the process of gifted child determination and support at an educational institution (common secondary school). These conditions are the following:

1. Management of an educational institution on the basis of reliable measurement of activities by means of psychological and pedagogical monitoring of student cognitive abilities, aimed to solve the problem of gifted child timely identification, the possibility of timely adjustment of the support process and the development of giftedness. 
Mihail V. Kozhevnikov, Irina V. Lapchinskaia, Natalia Y. Korneeva, Petr Yu. Romanov y Natalia V. Uvarina

2. Organization of a personality-oriented developing educational environment based on the use of personality-oriented educational technologies, aimed at interaction and personal self-development provision.

3. Organization of research activities by inclusion of all subjects of education in project activities aimed at the formation of value relationships, and motivation of gifted students.

The essence of the study was to evaluate the effectiveness of organizational and pedagogical conditions for effective management of the system for gifted student identification and support based on personalityoriented technologies. The results of the experimental work show positive changes in the following elements of educational organizations:

- innovative activity of teachers.

- the innovative component of educational programs.

- the introduction of innovative forms and methods in the activities of the collective educational organization.

- the educational space of the school (students are more satisfied with the organization of research activities at the school).

The study confirmed the effectiveness of gifted student support management in an educational organization.

\section{Conflict of interest}

The authors confirm that the presented data do not contain a conflict of interest.

\section{Bibliographic References}

ZHADRINA, Morento. 200o. "Differentiation as the condition for the implementation of variable educational training of gifted children" In: Daryn. No. 3, pp. 71-81 (in Russian).

ZHEKSENBAEVA, Ulenda. 2004. Theory and practice of working with gifted children: the monograph. Kaz. NPU named after Abay. Almaty, Kazakhstan. 
KOZHEVNIKOV, Mikel; LAPCHINSKAYA, Inera. 2019. "Management of gifted child development process in a school environment" In: Vocational education improvement in the context of the competencybased approach material implementation of All-Russian Scientific and Practical Conference. Magnitogorsk, Russia (in Russian).

LEITES, Natalie. 2008. "Age giftedness and individual differences: collection of works" 3rd ed., rev. and add. - M.: MPSI; Voronezh: MODEK, - 478 p. [in Russian].

SMAGLIY, Tedy; BIKBULATOV, Robert. 2017. Psychological and pedagogical foundations for the development of intellectually gifted students: the textbook. KSPI. Kostanay, Kazakhstan.

SHUMAKOVA, Nemaro. 2017, "Interdisciplinary training of gifted children at primary school” In: Perspective. P. 100 (in Russian).

YASVIN, Veda. 2007. "Examination of the school educational environment" In: Educational and Publishing Center "Academy”. P. 123 (in Russian).

DOLGOVA, Vandi; BELIKOV, Vikeda; KOZHEVNIKOV, Manela. 2019. "Partnership as a factor in the effectiveness of practice-oriented education of students" In: International Journal of Education and Practice. Vol. 7, No. 2, pp. 78-87. 


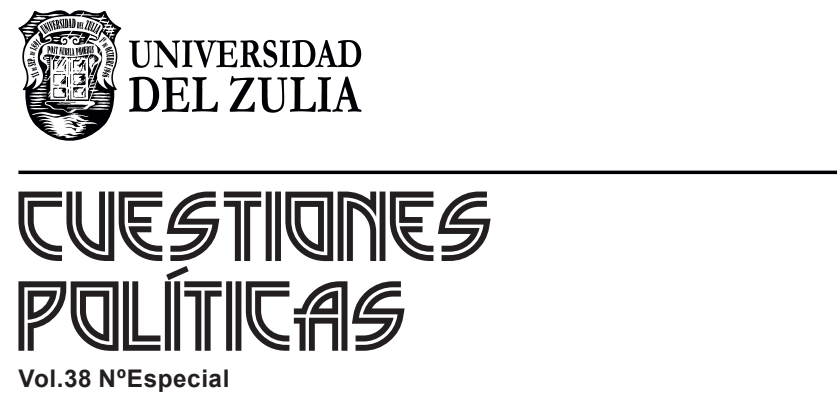

www.luz.edu.ve 